\title{
Pre-Service Teachers' Metaphorical Perceptions Regarding the Concept of Curriculum
}

\section{Orhan Akınoğlu}

Prof. Dr., Marmara University, Atatürk Faculty of Education, Department of Educational Sciences, Turkey, oakinoglu@marmara.edu.tr

The purpose of this study was to reveal pre-service teachers' perceptions regarding the concept of 'curriculum' through metaphors. Phenomenology, which is one of the qualitative research designs, was used in the study. Data of the study was obtained by asking a total of 123 pre-service teachers, including 84 females and 39 males and studying at various departments in Ataturk Faculty of Education at Marmara University in Turkey in the spring semester of 2013-2014 academic year, to complete the statement "Curriculum is like ........ Because.......". The collected data was analysed by content analysis technique and interpreted. According to the findings of the study, pre-service teachers produced a total number of 107 valid metaphors regarding the concept of 'curriculum', which were then categorized by considering their common features. Eight categories were obtained for the concept of 'curriculum'. In general, pre-service teachers were found to have positive perceptions regarding the concept of 'curriculum'.

Key Words: curriculum, curriculum perception, metaphor, teacher education, learning and teaching, phenomenology

\section{INTRODUCTION}

The concept of metaphor, which involves broad knowledge and a long history, is seen as an essential tool in thinking system (Fauconnier \& Turner, 2008; Kliebard, 1982; Kövecses, 2005). Metaphors, which are mostly perceived as a literary/poetic language and thought to be related to words, is a phenomenon which exists not only in the field of language but also in ideas and acts in everyday life (Gibbs \& Matlock, 2010; Lakoff \& Johnson, 2003). Metaphors, which are not merely rhetoric or figurative expressions, are also important in functioning of the mind (Martineza et al., 2001). Metaphors that reflect the thinking processes serve as the sources for thinking, language and scientific research (Semino \& Steen, 2008).

Metaphors reflect the thoughts of a person generating a metaphor as well as the person interpreting that metaphor (Davidson, 1978; Müller, 2008). Metaphors allow indirect

Citation: Akınoğlu, O. (2017). Pre-Service Teachers' Metaphorical Perceptions Regarding the Concept of Curriculum. International Journal of Instruction, 10(2), 263-278. https://doi.org/10.12973/iji.2017.10217a 
comparisons to be made between a more familiar thought or object and another thought or object; thus associations with abstract thoughts can be made more easily (Seiler, 2013). However, metaphors not only consist of comparisons but also allow certain new elements of experienced things to be noticed (Cameron, 2010; Saban, 2006). Metaphors, which are known as tools used voluntarily or involuntarily by individuals in their daily lives to define a concept using similes, help reflecting individuals' experiences and identifying their perceptions (Aykaç \& Çelik, 2014; Cameron \& Maslen, 2010; Low, 2008).

The concept of 'curriculum' which is the basic concept in curriculum development area in education, is traditionally considered as a list of courses; however, over time, it has been associated with student experiences, targets, learning outcomes and planning (Ornstein \& Hankins, 1988; Saylor et al., 1981; Tyler, 1950; Wiles \& Bondi, 2011). Curricula have a complex structure in social and educational terms and are seen as a total of students' experiences at school. Curricula provide guidance on learning experiences, changes expected to occur in behaviors, teaching materials, and processes involving assessment of teaching methods, techniques and approaches (Igbokwe et al., 2014; Kauchak \& Eggen, 2012; Marsh \& Willis, 2007). Curriculum, which is the basic element in an education system, covers targets expected to be achieved, content associated with targets, educational conditions and assessment conditions. Curriculum, which derives from the verb "currere" meaning "to run, to proceed", is particularly used in the sense of running a lecture (Doll, 2002), whereas teaching program is defined as all learning and teaching activities for making students achieve targets of a course both inside and outside a school (Demirel, 2012). In any society, curricula are expected to be continuous, flexible and dynamic so that they give response to changes in science and technology (Hewitt, 2006; Ornstein \& Hankins, 1988).

\section{CONTEXT AND LITERATURE REVIEW}

There's a variety of metaphor studies on curriculum and concepts related to curriculum. Metaphors, which are used to make abstract concepts and facts more concrete and familiar, are also utilized to understand the theoretical aspects of curricula (Kliebard, 1982). Views about curriculum can be better explained using metaphorical images (Doll, 2002). Metaphors such as machinery, engineering, quality control are used with regard to curriculum planning area with a specific historical and cultural context (MacDonald \& Purpel, 1987). In a study by Örten and Erginer (2010) on metaphorical perceptions of faculty from curriculum development field regarding curriculum and curriculum development, metaphors produced regarding curriculum were classified under the themes of "guidance, sequence, continuous change, planning and system" and metaphors regarding the science of curriculum development were classified under the themes of "aesthetics and creativity, depth, individual interpretation and sequence". Similarly, Simon (2013) explained the curriculum development process using the metaphor of "rug weaving" in order to explain the meaning of complex and interrelated structure in curriculum development process better and emphasize artistic nature of the process. 
In previous studies on investigation of perceptions of teachers and pre-service teachers regarding curriculum through metaphors, it was concluded that teachers produce negative metaphors on curriculum and curriculum development (Aykaç \& Çelik, 2014; Semerci, 2007), whereas pre-service teachers have positive perceptions of curriculum in general (Aykaç \& Çelik, 2014; Gültekin, 2013; Özdemir, 2012). Doll (2002) examined curricula using the metaphor "ghost" and suggested that curricula have the characteristics of a ghost, which can be felt but does not have any material substance. Baptist (2002) addressed curriculum as the metaphor of "garden" and studied it in terms of individual or political skills, layout, cultural expression, being unified and growth. In Anglin and Dugan's (1982) study on metaphors related to curriculum, they concluded that primary school teachers produce metaphors focused on development regarding curriculum, while secondary school teachers produce product-oriented metaphors. Metaphor studies on curriculum reveal perceptions of teachers and pre-service teachers, who implement and will implement the curriculum.

In view of the literature, metaphor studies on various concepts in educational science field have recently become widespread. Some of these studies focus on teacher (Hasim et al., 2013; Karadağ \& Gültekin, 2012; Koç, 2014), student (Saban, 2010), learning and teaching (Leavya et al., 2007; Saban et al., 2007; Tannehill \& MacPhail, 2014), knowledge, learning and learner (Kalraa \& Baveja, 2012), teacher, teaching, learning, teaching material and assessment (Eren \& Tekinarslan, 2013), teaching and literacy (Shaw \& Mahlios, 2008), educational planning (Boyac1, 2009), classroom (Levine, 2005; Uzun \& Paliç, 2013), classroom and classroom management (Örücü, 2012), school and ideal school (Özdemir \& Akkaya, 2013), university (Dalgıç et al., 2012), professional identity (Thomas \& Beauchamp, 2011), scientist (Akınoğlu et al., 2015), scientific thinking (Akınoğlu \& Eren-Dilek, 2015). Hence, metaphors combining theory and practice in education allow conscious analysis of the results revealed by theory and practice (Jensen, 2006; Levine, 2005).

Metaphor studies conducted with pre-service teachers help them examine their perceptions and beliefs regarding teaching and learning concepts, and organize them, where necessary, so they have important implications in terms of teacher education (Leavya et al., 2007; Low, 2008; Saban, 2010). Accordingly, the purpose of this study was to identify pre-service teachers' perceptions regarding the concept of 'curriculum' through metaphors. The study sought for an answer to the following research question "What are the pre-service teachers' metaphorical perceptions towards the concept of curriculum?". Accordingly, the following sub-questions were developed:

1) Which metaphorical images do pre-service teachers use regarding the concept of 'curriculum'?

2) Under which categories is it possible to classify pre-service teachers' metaphors regarding the concept of 'curriculum'?

\section{METHOD}

Research design, study group, data collection tool, data collection procedure, data analysis, and validity and reliability issues are presented in this section. 


\section{Research Design}

Phenomenological design, one of the qualitative research designs, was used in the study. Phenomenological design is used to investigate phenomena of which a researcher is aware but doesn't have in-depth knowledge (Bogdan \& Biklen, 1992; Creswell, 2007; Moustakas, 1994). Patton (2002) defines it as an approach which aims to focus on phenomena with which one isn't totally unfamiliar but the meaning of which cannot be fully grasped. In this context, the phenomenon on which the study focused was how preservice teachers conceptualized their thoughts about 'curriculum' using metaphors.

\section{Study Group}

Pre-service teachers participating in the study were chosen by opportunity sampling method. The study group consisted of 123 pre-service teachers studying at various departments in Atatürk Faculty of Education at Marmara University in 2013-2014 academic year. Of these pre-service teachers, 84 were females and 39 were males, and their distribution by department was as follows: 38 from Department of English Language Teaching, 10 from Department of Music Teaching, 23 from Department of French Language Teaching, 27 from Department of Religious Culture and Moral Education and 25 from Department of Psychological Counselling and Guidance.

\section{Data Collection Tool}

Data collection tool, which was developed by the researcher, was a fill-in-the-blanks form used to collect answers to several demographic questions, metaphors to be produced and explanations to these metaphors.

\section{Data Collection Procedure}

Metaphors were collected on the basis of vehicle-topic relation, after which pre-service teachers were asked to define similarity relationship according to how they perceive such relationship (Curriculum is like ...... because ........"). Main strength of metaphors is in questions related to adjectives. Each individual may attribute different meanings to the same metaphor. It's important to ask the question "why" in order to understand these various meanings and the purpose of using a metaphor (Patton, 2002; Yildirım \& Şimşek, 2013). Moreover, demographic data, including gender and department of preservice teachers, were collected.

\section{Data Analysis}

Content analysis, consisting of the stages of coding, finding themes and organizing data by codes and themes, was utilized to analyse the data. Content analysis is performed when a study cannot be clearly expressed theoretically or a more in-depth analysis is required (Creswell, 2007; Yıldırım \& Şimşek, 2013). Metaphors produced by the participants with regard to the question in the fill-in-the-blanks form and their responses were analysed in four stages: (1) coding data, (2) creating categories, (3) arranging the data by codes and categories (4) ensuring validity and reliability. The data was analysed by the researcher without employing any qualitative analysis software package. Furthermore, a number was assigned to each participant and next to this number, a code, 
which is "F" for female pre-service teachers and " $\mathrm{M}$ " for male pre-service teachers", was added. For example $93 \mathrm{~F}$ : The respective metaphor belongs to the 93rd person, who is a female pre-service teacher.

\section{Validity and Reliability}

Important criteria of validity in a qualitative research include detailed reporting of collected data and the researcher's description of how s/he obtained the results (Creswell, 2007; Yıldırım \& Şimşek, 2013). In this context, efforts were made to present the study data in detail (frequency, number of participants, direct quotations, codes of participants, etc.) as much as possible and explain how the results were obtained by conceptual categories.

With regard to the reliability of the study, five experts were consulted in order to determine whether the obtained metaphors represent the identified themes, and as a result of the evaluations of the researcher and the experts, consensus and dissent values were calculated. In general, percentages of 70 and above are assessed as "satisfactory" and those above 90 as "good" (Miles \& Huberman, 1994). At the end of this calculation, a reliability percentage of $94 \%$ was obtained for this study.

\section{FINDINGS}

In this section, pre-service teachers' metaphors regarding the concept of curriculum and frequencies of these metaphors are presented. Then, the categories created from these metaphors are explained by including quotations from the participants' statements.

\section{Pre-service Teachers' Metaphors Regarding the Concept of Curriculum and Their Frequencies}

When pre-service teachers' metaphors regarding the concept of curriculum are evaluated, a total of 107 valid metaphors, including 76 different metaphors, were obtained from 123 pre-service teachers.

Pre-service teachers' main metaphors regarding the concept of curriculum by frequency were as follows: compass (6), road (6), guide (3), outfit (3), frame (3), ocean (3), contents of a book (2), development (2), map (2), tree (2), cooking (2), car (2), plate (2), school (2), umbrella (2), mother (2), life (2), plan (2) and food (2). Remaining metaphors had a frequency value of 1 and those metaphors can be listed as follows: menu (1), set (1), library (1), train (1), state (1), diet program (1), travel (1) pool (1), salt (1), prescription (1), zip file (1), construction (1), home (1), shopping list (1), building (1), anthill (1), fish (1), love (1), street (1), chewing gum (1), stage of development (1), ladder (1), a man's own captivity (1), order (1), living thing (1), art (1), goldsmith (1), the solar system (1), insect (1), sky (1), branch (1), vitamin (1), orbit (1), machinery (1), star (1), calendar (1), gift package (1), wood (1), brain (1), cliff (1), politics (1), seed (1), marriage (1), play dough (1), sewage (1), fruit (1), ship (1), handcuffs (1), coffee (1), functioning of nature (1), elective course (1), brochure (1), recipe (1), sea (1), spider web (1), ingredient (1), order (1). 


\section{Pre-service Teachers' Reasons for Their Metaphors Regarding Curriculum}

Pre-service teachers' reasons for their metaphors regarding curriculum are given in Table 1 under the following categories: curriculum as a guide $(n=26)$, curriculum as a wide range $(\mathrm{n}=17)$, curriculum as a source of problem $(\mathrm{n}=16)$, curriculum as an organizer $(n=15)$, curriculum as a source of information $(n=12)$, curriculum as a process $(\mathrm{n}=8)$, curriculum as an indispensable element $(\mathrm{n}=8)$ and curriculum as a means for achieving a specific outcome $(n=5)$. These categories were revealed by examining the causes of the metaphors obtained.

Table 1.

Reasons for metaphors regarding the concept of curriculum

\begin{tabular}{lll}
\hline Categories & Metaphors & N (Number) \\
\hline Curriculum as a guide & $\begin{array}{l}\text { contents of a book (2), map, road (4), menu, plate, } \\
\text { pool, compass (6), plan, orbit, outfit (2), guide (3), } \\
\text { play dough, recipe, ingredient }\end{array}$ & 26 \\
\hline Curriculum as a wide range & $\begin{array}{l}\text { fish, frame, ocean (3), living thing, school, umbrella } \\
\text { (2), art, insect, branch, outfit, car, sea, tree, spider } \\
\text { web }\end{array}$ & 17 \\
\hline $\begin{array}{l}\text { Curriculum as a source of } \\
\text { problem }\end{array}$ & $\begin{array}{l}\text { plate, zip file, gum, life, man's own captivity, food, } \\
\text { gift package, cliff, politics, road, sewage, fruit, } \\
\text { handcuffs, coffee, elective course, frame }\end{array}$ & 16 \\
\hline Curriculum as an organizer & $\begin{array}{l}\text { marriage, development(2), cooking, set, state, } \\
\text { prescription, frame, street, order, calendar, brain, } \\
\text { functioning of nature, map, plan }\end{array}$ & 15 \\
\hline $\begin{array}{l}\text { Curriculum as a source of } \\
\text { information }\end{array}$ & $\begin{array}{l}\text { goldsmith, construction, library, building, mother, } \\
\text { sky, vitamin, machinery, star, seed, brochure, school }\end{array}$ & 12 \\
\hline Curriculum as a process & $\begin{array}{l}\text { ladder, wood, stage of development, cooking, mother, } \\
\text { anthill, road, life }\end{array}$ & 8 \\
\hline $\begin{array}{l}\text { Curriculum as an } \\
\text { indispensable element }\end{array}$ & $\begin{array}{l}\text { tree, shopping list, diet program, salt, home, solar } \\
\text { system, food, order }\end{array}$ & 8 \\
\hline Curriculum as a means to & $\begin{array}{l}\text { car, train, travel, love, ship } \\
\text { achieve a particular outcome }\end{array}$ & 5 \\
\hline Total & & 107 \\
\hline
\end{tabular}

Some of the statements of the participants regarding the categories in Table 1 are as follows:

\section{a) Curriculum as a Guide}

Some of the statements of the participants on the fact that curriculum functions as a guide in that it contains the subjects to be taught, orientates the teacher and provides guidelines to the teacher are presented below:

"It contains a list of what should be taught" (15 M).

"It provides guidance" (32 F).

"It contains all guidelines" (36 M). 
"It helps us find our direction" (82 M).

"A person knows how and where to act. As in what to wear in which place ..." (99 F).

b) Curriculum as a Wide Range

Some of the statements of the participants on the fact that curriculum is quite detailed, comprehensive and compatible with other programs are presented below:

"It's very deep" (18 F).

"It's comprehensive" (34 M).

"It contains in-depth information" (66 M).

"It integrates with other programs" (77 F).

"It includes all kinds of information" (93 F).

c) Curriculum as a Source of Problem

Some of the statements of the participants on the fact that curriculum sometimes allows a student to acquire negative information and skills, it may limit the teacher's autonomy, that these curricula are presented to teachers without consulting them and that these curricula may sometimes become complex are presented below:

"It fills an empty plate in a terrible way" (24 F).

"It restricts education for no apparent reason" (42 M).

"Even elective courses are selected without informing us and placed right in front of us" (69 F).

"From the outside, it looks perfect but has very few benefits" (84 F).

"As you examine it, it becomes complex and never gives accurate and precise results" (88 F).

d) Curriculum as an Organizer

Some of the statements of the participants on the fact that curriculum organizes teaching are presented below:

"Cooking should be done in a specific order" (22 F).

"It puts everything in order" (64 M).

"It organizes things" (86 F).

"It regulates method of teaching" (102 F).

"It's disciplined" (119 M).

e) Curriculum as a Source of Information 
Some of the statements of the participants on the fact that curriculum provides the teacher with accurate and comprehensive information, provides the student with information and contains basic principles of the profession are presented below:

"Accurate information is in the book" (28 M).

"It provides people with information on a wide range of fields" (75 M).

"It processes the student and helps him/her learn $(80 \mathrm{~F})$.

"As people learn information it contains and improve, they shine/gleam" (81 F).

"It forms the basis of our profession" (89 M).

f) Curriculum as a Process

Some of the statements of the participants on the fact that curriculum can be implemented step by step in a certain order and is strung out are presented below:

"It's taken step by step" (1 M).

"It develops in an order" (20 M).

"It continues step by step" (33 F).

"It has thousands of miles" (61 F).

"It continues" (122 F).

g) Curriculum as an Indispensable Element

Some of the statements of the participants on the fact that curriculum is very important and vital for teaching are presented below:

"There's no life without it" (8 M).

"It is essential for weight loss" (21 M).

"Without it, the final product won't have taste" (37 M).

"It's essential for education and is the cornerstone of education" (48 F).

"It's the inventory of life" (103 M).

\section{h) Curriculum as a Means to Achieve a Particular Outcome}

Some of the statements of the participants on the fact that curriculum is a means of achieving educational objectives are presented below:

"It's an activity car" (35 M).

"You can even teach to love" (57 F).

"It allows you to know where you'll reach" (97 F). 


\section{DISCUSSION AND CONCLUSION}

In this study, pre-service teachers developed a total number of 107 valid metaphors regarding the concept of curriculum. Of these metaphors, there're 60 positive metaphors in 76 different metaphors. It was concluded that pre-service teachers usually have positive perceptions of curriculum. This result of the study is similar to those reported by Gültekin (2013), Özdemir (2012), Taşdemir and Taşdemir (2011) and Aykaç and Çelik (2014) in this respect. However, Semerci (2007) maintained that teachers have negative views about new primary school curricula, which outweigh positive views. Moreover, in a study conducted on primary school teachers by Yurdakul (2015), teachers used the metaphor of "chain" for the existing curriculum, so it was concluded that teachers think that curriculum restricts teachers' behaviors. This difference was thought to be associated with the role of teachers who personally implement curriculum.

In this study, main characteristics of curriculum were identified as guiding and organizing, while in a study by Aykaç and Çelik (2014), curriculum was perceived as restrictive and uniform rules. In this respect, these two studies do not coincide with each other. However, Taşdemir and Taşdemir (2011) reported that teachers perceive primary school curricula as "a guide" in general and Örten and Erginer (2010) reported that curriculum is expressed as "guiding". Similarly, Bartiromo and Etkina (2009) concluded that teachers have positive perceptions of curriculum. In this context, these studies are similar. Various perceptions of curriculum were thought to be the result of different understandings and perceptions of teachers and pre-service teachers regarding curriculum as well as differences between their practices, knowledge and skills.

In this study, one of the obtained categories was curriculum as a means of achieving a particular outcome. Similarly, Aykaç and Çelik (2014) reported that curriculum is perceived as a means of achieving a target. In a similar study, it was concluded that teachers perceive curriculum as a 'journey' (Anglin \& Dugan, 1982). In this respect, these three studies are in line with each other. Education systems have far, close and specific objectives. Curriculum is one of the most special means of achieving these targets. In this regard, it appears quiet realistic that curricula are perceived as a means of achieving targets or outcomes.

In this study, it emerged that curriculum causes problems. However, it guides and organizes things. It is a wide range and an indispensable element. In line with this, Gültekin (2013) reported that curriculum is perceived as a complex structure causing problems, a cornerstone, a wide range, guide and shaper. 'Development' metaphor, which is also in the category of "curriculum as an organizer", is one of the metaphors produced by teachers in Anglin and Dugan's (1982) study. Baptist (2002) used the metaphor of "garden" to draw attention to dimensions of curriculum and associated the order in a garden with order in curriculum. The metaphor of order is one of the metaphors generated in this study. In this context, our study is in line with Baptist's (2002) study. In previous studies, organizing role of curricula was emphasized, which indicates that curricula are considered important in terms of the fact that they organize the processes of teaching and learning in particular. 
In this study, it was revealed that curriculum is perceived as a guide, a process, means of achieving a particular outcome and an indispensable element. Similar perceptions were also reported by Özdemir (2012). Also in this study, it was seen that pre-service teachers used the metaphor of "machine" in the category of "curriculum as a source of information". The metaphor of machine is also one of the metaphors used for curriculum planning (MacDonald \& Purpel, 1987). In that case, the studies are similar in that they emphasize that curricula provide guidance. Pre-service teachers' metaphors regarding curriculum included the metaphors of "journey" and "map", which indicates that they see curriculum as a means of achieving a goal or a guide that will lead to a goal. The same metaphors are referred to as metaphors showing the relationship between theory and practice by Mullen, Greenlee and Bruner's (2005) study. Curricula were seen as a guide in the journey from theory to practice, which may suggest that pre-service teachers are aware of curricula.

Among 76 different metaphors produced regarding the concept of "curriculum" by preservice teachers, there were only 16 negative metaphors, including "plate", "zip file", "chewing gum", "life", "a man's own captivity", "food", "gift package", "cliff", "politics", "road", "sewage", "fruit", "handcuffs", "coffee "," elective course" and " frame ". In this study, a great majority of pre-service teachers can be said to have positive perceptions of "curriculum".

\section{RECOMMENDATIONS}

The study group of this study was pre-service teachers. Study groups of similar further studies can be the students, teachers or lecturers who are doing or have done postgraduate studies in the field of curricula. Also, after collection of metaphors, interviews can be made with a group of participants in the same study group in order to obtain more in-depth and detailed data.

\section{REFERENCES}

Akinoglu, O., Tatik, R.S., \& Baykin, Y. (2015). Pre-service teachers' metaphorical perceptions towards the concept of scientist. Antropologist, 19 (3), 577-584.

Akinoglu, O., \& Eren-Dilek, C. (2015). Pre-service teachers' metaphors regarding the concept of scientific thinking. Antropologist, 20 (3), 476-484.

Anglin, L.W., \& Dugan, T. (1982). Teachers' perceptions of existing and ideal school curriculum: An analysis of metaphors. Paper presented at the Annual Meeting of the American Educational Research Association, New York. ERIC Number: ED217037.

Aykaç, N., \& Çelik, Ö. (2014). Comparison of metaphoric perception of teachers and pre-service teachers about curriculum. Education and Science, 39 (173), 326-339.

Baptist, K.W. (2002). The garden as metaphor for curriculum. Teacher Education Quarterly, 29 (4) 19-37.

Bartiromo, T., \& Etkina, E. (2009). Implementing reform: Teachers' beliefs about students and the curriculum. AIP Conference Proceedings, 1179, 468-489. 
Bogdan, R. C., \& Biklen, S. K. (1992). Qualitative research for education: An introduction to theory and methods. Boston: Allyn and Bacon.

Boyac1, A. (2009). Metaphorical images for educational planning: Perceptions of public elementary school teachers. Selçuk University Institute of Social Sciences Journal, 21, 111-124.

Cameron, L. (2010). What is metaphor and why does it matter? In L. Cameron \& R. Maslen (Eds.), Metaphor analysis (pp. 3-25). London: Equinox.

Cameron, L., \& Maslen, R. (Eds.). (2010). Metaphor analysis. London: Equinox.

Creswell, W. J. (2007). Qualitative inquiry and research design: Choosing among five approaches (Second Edition).Thousand Oaks, CA: SAGE Publications.

Dalgıç, G., Karadeniz, Ş., \& Onat, E. C. (2012). Towards a new understanding of university through metaphors. Educational Administration: Theory and Practice, 18 (3), 377-398.

Davidson, D. (1978). What metaphors mean. Critical Inquiry, 5 (1), 31-47.

Demirel, Ö. (2012). Eğitimde program geliştirme [Curriculum development in education] (18th edition). Ankara: Pegem A Publishing.

Doll, W.E. Jr. (2002). Ghosts and the curriculum. In W. E. Jr. Doll, \& N. Gough (Eds.) Curriculum visions (pp.23-72). New York, NY: Peter Lang.

Eren, A., \& Tekinarslan, E. (2013). Prospective teachers' metaphors: Teacher, teaching, learning, instructional material and evaluation concepts. International J. Soc. Sci. \& Education, 3 (2), 435-445.

Fauconnier, G., \& Turner, M. (2008). Rethinking metaphor. In R. Gibbs (Ed.) The Cambridge handbook of metaphor and thought (pp. 53-66). Cambridge: Cambridge University Press.

Gibbs, R., \& Matlock, T. (2008). Metaphor, imagination, and simulation. In R.Gibbs (Ed.), The Cambridge handbook of metaphor and thought (pp. 161-176). Cambridge: Cambridge University Press.

Gültekin, M. (2013). The metaphors that primary education teacher candidates use regarding curriculum. Education and Science, 38 (169), 126-141.

Hasim, Z., Mohtar, T.M.T., Barnard, R., \& Zakaria, A.R. (2013). Metaphors used by Malaysian teachers-in-training: Implications for language teacher education. Creative Education, 4 (9), 74-77.

Hewitt, T. W. (2006). Understanding and shaping curriculum: What we teach and why? Thousand Oaks, CA: Sage.

Igbokwe, U.L., Mezieobi, D.I., \& Eke, C. (2014). Teachers' attitude to curriculum change: Implications for inclusive education in Nigeria. Research on Humanities and Social Sciences, 4 (11), 92-99. 
Jensen, D.F.N. (2006). Metaphors as a bridge to understanding educational and social contexts. International Journal of Qualitative Methods, 5 (1), 36-54.

Kalraa, M.B., \& Baveja, B. (2012). Teacher thinking about knowledge, learning and learners: A metaphor analysis. Procedia - Social and Behavioral Sciences, 55, 317-326.

Karadağ, R., \& Gültekin, M. (2012). The metaphors that elementary school students use to describe the term "teacher". Mersin University Journal of the Faculty of Education, 8 (1), 69-83.

Kauchak, D., \& Eggen, P. (2012). Learning and teaching: Research-based methods. Boston: Pearson.

Kliebard, H.M. (1982). Curriculum theory as metaphor. Theory into Practice, 21 (1), $11-17$.

Koç, E. (2014). The metaphorical perceptions of classroom teacher candidates regarding teacher and teaching profession concepts. Inönü University Journal of the Faculty of Education, 15 (1), 47-72.

Kövecses, Z. (2005). Metaphor in culture: Universality and variation. Cambridge, UK: Cambridge University Press.

Lakoff, G., \& Johnson, M. (2003). Metaphors we live by. London: The University of Chicago Press.

Leavya, A.M., McSorleya, F.A., \& Bote, L.A. (2007). An examination of what metaphor construction reveals about the evolution of pre-service teachers' beliefs about teaching and learning. Teaching and Teacher Education, 23, 1217-1233.

Levine, P. M. (2005). Metaphors and images of classrooms. Kappa Delta Pi Record, 4l(4), 172-175.

Low, G. (2008). Metaphor and education. In R. Gibbs (Ed.), The Cambridge handbook of metaphor and thought (pp. 212-231). Cambridge: Cambridge University Press.

MacDonald, J.B., \& Purpel, D.E. (1987). Curriculum and planning: Visions and metaphors. Journal of Curriculum and Supervision, 2 (2), 178-192.

Marsh, J. C., \& Willis, G. (2007). Curriculum: Alternative approaches, ongoing issues (4th Ed.). NJ: Prentice Hall.

Martineza, M.A., Sauledaa, N., \& Huberb, G.L. (2001). Metaphors as blueprints of thinking about teaching and learning. Teaching and Teacher Education, 17, 965-977.

Miles, M.B., \& Huberman, A.M. (1994). Qualitative data analysis: An expanded sourcebook (2nd Ed.). Thousand Oaks, CA: SAGE.

Moustakas, C. (1994). Phenomenological research methods. Thousand Oaks, CA: Sage. 
Mullen, C.A., Greenlee, B.J., \& Bruner, D.Y. (2005). Exploring the theory-practice relationship in educational leadership curriculum though metaphor. International Journal of Teaching and Learning in Higher Education, 17 (1), 1-14.

Müller, C. (2008). Metaphors dead and alive, sleeping and waking. Chicago: The University of Chicago Press.

Ornstein, A., \& Hankins, F.H. (1988). Curriculum foundations, principles and issues. NJ: Prentice Hall, Englewood Cliffs.

Örten, D., \& Erginer, E. (2010). Türkiye'de eğitimde program geliştirme alanındaki öncü akademisyenlerin eğitimde program geliştirmeye ilişkin metaforik algıları. [The metaphorical perceptions of the pioneer academicians in the field of curriculum development in Turkey about curriculum development]. 1st National Curriculum Development and Teaching Congress. Balıkesir: Balıkesir University Necatibey Education Faculty and Curriculum and Teaching Association.

Örücü, D. (2012). Primary school teachers' metaphorical perspectives towards classroom and classroom management: A comparative case study. Elementary Education Online, 11 (2), 342-352.

Özdemir, S.M. (2012). Metaphoric perceptions of prospective teachers regarding the concept of curriculum. Journal of Theoretical Educational Science, 5 (3), 369-393.

Özdemir, S., \& Akkaya, E. (2013). The analysis of secondary school students' and teachers' mental images of school and ideal school by using metaphor. Educational Administration: Theory and Practice, 19 (2), 295-322.

Patton, M. Q. (2002). Qualitative research and evaluation methods (3rd Ed.). Thousand Oaks, CA: Sage.

Saban, A. (2006) Functions of metaphor in teaching and teacher education: A review essay. Teaching Education, 17 (4), 299-315.

Saban, A. (2010). Prospective teachers' metaphorical conceptualizations of learner. Teaching and Teacher Education, 26, 290-305.

Saban, A., Kocbeker, B. N., \& Saban, A. (2007). Prospective teachers' conceptions of teaching and learning revealed through metaphor analysis. Learning and Instruction, 17 (2), 123-139.

Saylor, J., Alexander, W., \& Lewis, A. (1981). Curriculum planning for better teaching and learning (4th Ed.) New York: Holt, Rinehart \& Winston.

Seiler, G. (2013). New metaphors about culture: Implications for research in science teacher preparation. Journal of Research in Science Teaching, 50 (1), 104-121.

Semerci, Ç. (2007). A view to the new primary school curricula with the metaphors relating to "curriculum development. Çukurova University Instute of Social Sciences Journal, 31 (2), 125-140.

Semino, E., \& Steen, G.J. (2008). Metaphor in literature. In R. Gibbs (Ed.) The Cambridge handbook of metaphor and thought (pp. 232-246). Cambridge: Cambridge University Press. 
Shaw, D.M., \& Mahlios, M. (2008). Pre-service teachers' metaphors of teaching and literacy. Reading Psychology, 29 (1), 31-60.

Simon, S.E. (2013). The weaving of a tapestry: A metaphor for teacher education curriculum development. Australian Journal of Teacher Education, 38 (8).73-91.

Taşdemir, M., \& Taşdemir, A. (2011). İlköğretim programı üzerine öğretmen metaforları. [Teachers' metaphors about primary education curriculum.] In Z. Kaya \& U. Demiray (Eds.), 2nd International Conference on New Trends in Education and Their Implications, (pp. 795-809). Antalya, Turkey.

Tannehill, D., \& MacPhail, A. (2014). What examining teaching metaphors tells us about pre-service teachers' developing beliefs about teaching and learning?. Physical Education and Sport Pedagogy, 19 (2), 149-163.

Thomas, L., \& Beauchamp, C. (2011). Understanding new teachers' professional identities through metaphor. Teaching and Teacher Education, 27, 762-769.

Tyler, R. (1950). Basic principles of curriculum and instruction. Chicago: University of Chicago Press.

Uzun, S., \& Paliç, G. (2013). Analysis of primary school teachers' perceptions about the concept of classroom through metaphors. Usak University Journal of Social Sciences, 6 (4), 245-260.

Wiles, J., \& Bondi, J. (2011). Curriculum development: A guide to practice (8th Ed.). New Jersey: Pearson Education Inc.

Yıldırım, A., \& Şimșek, H. (2013). Sosyal bilimlerde nitel araștırma yöntemleri. [Qualitative research methods in social studies.] Ankara: Seckin Publishing.

Yurdakul, B. (2015). Perceptions of elementary school teachers concerning the concept of curriculum. Educational Sciences: Theory \& Practice, 15 (1), 125-139.

\section{Turkish Abstract \\ Öğretmen Adaylarının, Öğretim Programı Kavramına Yönelik Metaforik Algıları}

$\mathrm{Bu}$ araştırmanın amacı, öğretmen adaylarının “öğretim programı” kavramına yönelik sahip oldukları algıları metaforlar aracılığıyla ortaya çıkarmaktır. Çalışmada, nitel araştırma desenlerinden olgubilim deseni kullanılmıştır. Araştırmanın verileri, 2013-2014 eğitim-öğretim yılı bahar döneminde, Türkiye'deki Marmara Üniversitesi Atatürk Eğitim Fakültesi'nde çeşitli bölümlerde öğrenim gören 84 kadın, 39 erkek olmak üzere toplam 123 öğretmen adayının "öğretim programı ...... gibidir. Çünkü ....." ifadelerini tamamlamasıyla elde edilmiştir. Toplanan veriler içerik analizi tekniği ile analiz edilmiş ve yorumlanmıştır. Elde edilen bulgulara göre, öğretmen adayları, "Öğretim Programı" kavramı için 107 geçerli metafor üretmiştir. Üretilen bu metaforlar daha sonra ortak özellikleri dikkate alınarak kategorileştirilmiştir. “Öğretim programı” kavramı için 8 kategori elde edilmiştir. Öğretmen adaylarının genel anlamda "öğretim programı” algılarının olumlu yönde olduğu görülmüştür.

Anahtar Kelimeler: program, program algıları, metafor, öğretmen eğitimi, öğrenme ve öğretim, fenomonoloji 


\section{French Abstract}

\section{Pre-Service Teachers' Metaphorical Perceptions Regarding the Concept of Curriculum}

Le but de cette étude était de révéler les perceptions des professeurs de pré service quant au concept 'de programme d'études' par des métaphores. La phénoménologie, qui est un des designs(conceptions) de recherche qualitatifs, a été utilisée dans l'étude. Les données de l'étude ont été obtenues en demandant à un total de 123 professeurs de pré service, y compris 84 femelles et 39 mâles et étudiant aux départements divers dans la Faculté Ataturk d'Enseignement(Éducation) à l'Université Marbrée en Turquie en semestre à ressort(de printemps) de 2013-2014 an universitaire, compléter(achever) la déclaration "le Programme d'études ressemble à ....... . parce que.". Les données rassemblées ont été analysées par la technique d'analyse de contenu et interprétées. Selon les conclusions de l'étude, les professeurs de pré service ont produit un nombre total de 107 métaphores valables quant au concept "de programme d'études ', qui ont été alors catégorisés en considérant leurs caractéristiques communes. Huit catégories ont été obtenues pour le concept 'de programme d'études'. En général, les professeurs de pré service ont été trouvés pour avoir des perceptions positives quant au concept 'de programme d'études'.

Mots Clés: programme d'études, perception de programme d'études, métaphore, enseignement(éducation) de professeur, apprenant et enseignant, phénoménologie

\section{Arabic Abstract}

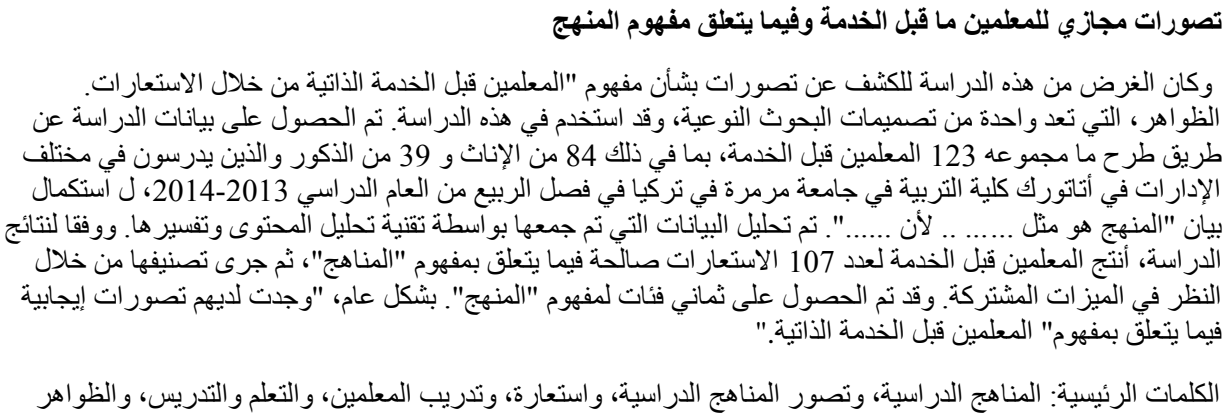

German Abstract

Metaphorische Wahrnehmung Pre-Service Lehrer in Bezug auf das Konzept des Curriculums

Der Zweck dieser Studie war es, die Vorstellungen der Lehrer über den Begriff des "Curriculums" durch Metaphern zu verraten. Die Phänomenologie, die eine der qualitativen Forschungsentwürfe ist, wurde in der Studie verwendet. Die Daten der Studie wurden durch die Erhebung von insgesamt 123 Pre-Service-Lehrer, darunter 84 Frauen und 39 Männer und Studium an verschiedenen Abteilungen in Ataturk Pedagogische Hochschule an der Marmara Universität in der Türkei im Frühjahrssemester 2013-2014 akademischen Jahr, bis Vervollständige die Aussage "Curriculum ist wie ...... .. Weil ......". Die gesammelten Daten wurden durch Inhaltsanalyse analysiert und interpretiert. Nach den Ergebnissen der Studie haben Pre-Service-Lehrer insgesamt 27 gültige Metaphern über den Begriff des "Curriculums" erstellt, die dann unter 
Berücksichtigung ihrer gemeinsamen Merkmale kategorisiert wurden. Für das Konzept des "Curriculums" wurden acht Kategorien gewonnen. Im Allgemeinen wurden Pre-Service-Lehrer "positive Wahrnehmungen hinsichtlich des Begriffs" Curriculum "gefunden.

Schlüsselwörter: curriculum wahrnehmung, metapher, lehrerausbildung, lernen und lehren, phänomenologie

\section{Malaysian Abstract \\ Persepsi Metafora Guru Pra- Perkhidmatan Mengenai Konsep Kurikulum}

Tujuan kajian ini adalah untuk mendedahkan persepsi mengenai konsep guru-guru pra perkhidmatan terhadap kurikulum melalui metafora. Fenomenologi, yang merupakan salah satu reka bentuk kajian kualitatif, telah digunakan dalam kajian ini. Data kajian ini telah diperoleh dengan meminta sejumlah 123 guru pra-perkhidmatan, termasuk 84 wanita dan 39 lelaki dan menuntut di pelbagai jabatan di Ataturk Fakulti Pendidikan di Universiti Marmara di Turki pada semester musim bunga 2013-2014 tahun akademik, untuk menyiapkan kenyataan "Kurikulum adalah seperti ........ Kerana .......". Data yang diperolehi dianalisis dengan menggunakan teknik analisis kandungan dan ditafsirkan. Menurut hasil kajian itu, guru-guru praperkhidmatan dihasilkan seramai 107 metafora sah mengenai konsep 'kurikulum', yang kemudiannya dikategorikan dengan mempertimbangkan ciri-ciri biasa mereka. Lapan kategori diperoleh bagi konsep 'kurikulum'. Secara umum, guru-guru pra-perkhidmatan 'didapati mempunyai persepsi positif mengenai konsep' kurikulum '.

Kata Kunci: kurikulum, persepsi kurikulum, metafora, pendidikan guru, pembelajaran dan pengajaran, fenomenologi

\section{Russian Abstract \\ Метафорическое Восприятие Учителя в Отношении Концепции Учебной Программы}

Цель этого исследования расследовать отношение директоров школ, руководителей и Цель этого исследования состояла в том, чтобы выявить восприятие учителями дошкольного образования концепции “учебного плана” с помощью метафор. Феноменология, которая является одним из качественных исследовательских проектов, была использована в исследовании. Данные исследования были получены путем опроса 123 учителей, из которых 84 женщины и 39 мужчин, а также обучения на различных факультетах образования Ататюрка в Университете Мармара в Турции в весенний семестр 2013-2014 учебного года, Для завершения заявления "Учебная программа подобна ... Потому что ...”. Собранные данные анализировались с помощью методики анализа контента и интерпретировались. Согласно результатам исследования, восприятие учитель произведенный в общей сложности 107 действительных метафор относительно понятия “учебный план”, которые затем были классифицированы с учетом их общих особенностей. Восемь категорий были получены для понятия “учебный план”. В целом, восприятие учители были прошедшие предварительную службу, обнаружили положительное восприятие родственный “учебный план”.

Ключевые Слова: учебная программа, восприятие учебного плана, метафора, педагогическое образование, обучение и преподавание, феноменология 